Research Report No. 30/2007

\title{
The ECJ, Volkswagen and European Corporate Law: Reshaping the European Varieties of Capitalism
}

Peer Zumbansen

Osgoode Hall Law School of York University, PZumbansen@osgoode.yorku.ca

Daniel Saam

Follow this and additional works at: http://digitalcommons.osgoode.yorku.ca/clpe

\section{Recommended Citation}

Zumbansen, Peer and Saam, Daniel, "The ECJ, Volkswagen and European Corporate Law: Reshaping the European Varieties of Capitalism" (2007). Comparative Research in Law \& Political Economy. Research Paper No. 30/2007.

http://digitalcommons.osgoode.yorku.ca/clpe/246 
Peer Zumbansen and Daniel Saam

The ECJ, Volkswagen and European Corporate Law: Reshaping the European Varieties of Capitalism

EDITORS: Peer Zumbansen (Osgoode Hall Law School, Toronto, Director, Comparative Research in Law and Political Economy, York University), J ohn W. Cioffi (University of California at Riverside), Lindsay Krauss (Osgoode Hall Law School, Toronto, Production Editor) 

CLPE Research Paper 30/2007

Vol. 03 No. 06 (2007)

Peer Zumbansen \& Daniel Saam

\title{
THE ECJ, VOLKSWAGEN AND EUROPEAN CORPORATE LAW: RESHAPING THE EUROPEAN VARIETIES OF CAPITALISM
}

\begin{abstract}
On 23 October 2007, the European Court of Justice handed down its much-awaited Volkswagen decision (Case C-112/2005), following a suit launched by the Commission against the Federal Republic of Germany in 2005. The Volkswagen statute, through which first the Federal government together with the Land (federal state) of Niedersachsen (Lower Saxony), later only Lower Saxony, had reserved a veto against majority acquisition while only holding a fifth of all shares, had come into the Commission's purview as part of its large-scale attempts at reforming and modernizing European company law. The preparatory steps in that regard had been the suits brought by the Commission with regard to other, 'golden share' provisions under Portuguese, French, Belgian and English company laws in recent years. Yet, the Volkswagen decision of the ECJ is of interest in more than one respect. Not only does it constitute a continuation and further accentuation of a line of argument that the Court has been unfolding over past few years with regard to the Member State provisions in conflict with the EC's guarantee of the free movement of capital as laid down in Art. 56 EC. In addition, the impact of the ECJ's new ruling will have to be assessed in the context of a high-powered regulatory field, in which member states, the Commission, and the Court have been finding themselves in an ongoing negotiation and contestation of historically grown company law regimes and the pressures of globalizing capital markets. In that regard, the Volkswagen decision raises a host of questions relating to the Commission's future agenda of corporate governance reform on the one hand and the persisting differences among member states' corporate law regimes on the other. The following article lays out the Court's reasoning, before observing both the immediate and the more long-term effect of the decision.
\end{abstract}


Keywords: Corporate Governance, European Corporate Law, Volkswagen, Golden Shares, Co-determination, Works Councils

JEL classification: G34, J29, J53, K22, K33

Published in: 8 GERMAn LAW JouRnal 1026-1051 (2007)

\section{Author Contacts:}

Peer Zumbansen

Associate Dean (Research, Graduate Studies \& Institutional Relations).

Director, CLPE Comparative Research in Law \& Political Economy

[www.comparativeresearch.net]; Co-Editor in Chief, German Law Journal

[www.germanlawjournal.com]

Osgoode Hall Law School, York University, Toronto ON

Email: pzumbansen@osgoode.yorku.ca

Daniel Saam

Johann Wolfgang Goethe University, Frankfurt

saam@jur.uni-frankfurt.de 



\title{
THE ECJ, VOLKSWAGEN AND EUROPEAN CORPORATE LAW: RESHAPING THE EUROPEAN VARIETIES OF CAPITALISM
}

\author{
Peer Zumbansen and Daniel Saam*
}

\section{INTRODUCTION}

On its website "The EU Single Market - Fewer barriers, more opportunities"1, the European Commission lists the judgments by the European Court of Justice [ECJ] dealing with the free movement of capital under Art 56 EC Treaty (ex 73b). The latest update of this list is the Court's Volkswagen decision of 23 October 2007 (Case C-112/2005), which the Commission had launched against the Federal Republic of Germany on 4 March 2005. ${ }^{2}$ This suit, brought under Art. 226 EC Treaty, had been long coming. ${ }^{3}$ That the Volkswagen statute, which effectively gave the Federal government and the Land (federal state) of

\footnotetext{
* Peer Zumbansen, Osgoode Hall Law School. Associate Dean (Research, Graduate Studies and Institutional Relations); Director, CLPE, www.comparativeresearch.net, CoEditor in Chief, German Law Journal. Email: Pzumbansen@osgoode.yorku.ca; Daniel Saam, Ph.D. Candidate, Johann Wolfgang Goethe-University, Frankfurt. Email: Saam@jur.uni-frankfurt.de. Thanks to the student editors of the German Law Journal at Osgoode Hall Law School for research assistance and to CLPE Fellow, Kirsteen Shields, Ph.D. Candidate at Queen Mary School of Law, University of London, UK, for helpful comments and to my colleague Cynthia Williams and the participants in Osgoode Hall's Legal Theory Seminar on 'Law and Economic Relations' for fruitful discussions.

${ }^{1}$ http://ec.europa.eu/internal_market/capital/framework/court_en.htm.

2 Case C-112/2005, dated 23 October 2007, Commission v. Federal Republic of Germany "Volkswagen".

${ }^{3}$ See only the European Commission's Press Release of 13 October 2004, IP/04/1209:

"The European Commission has decided to take Germany to the European Court of Justice with respect to certain provisions of a 1960 law privatising Volkswagen (VW law)...”, available at: http://europa.eu/rapid/pressReleasesAction.do?reference=IP/04/1209\&format=HTML\&a ged=1\&language=EN\&guiLanguage=en (last visited 27 October 2007).
} 
Niedersachsen (Lower Saxony) a veto against majority acquisition while only holding a fifth of all shares ${ }^{4}$, would come into the Commission's purview, could hardly surprise, given the Commission's activity with regard to such 'golden share' provisions under Portuguese, French, Belgian and English company laws. ${ }^{5}$ The most recent decision of the ECJ in the case of Volkswagen is of interest in more than one respect. Not only does it constitute a continuation and further accentuation of a line of argument that the Court has been unfolding over past few years with regard to the Member State provisions in conflict with the EC's guarantee of the free movement of capital as laid down in Art. 56 EC. The particular mentioning of the importance of the free movement of capital in Art. 14 para. $2 \mathrm{EC}$ for the realization of the internal market further underlines the place of this guarantee within the larger political and economic framework. After a longer period of relative marginalization in the struggle over positive vs. negative integration ${ }^{6}$, the increasing globalization of capital markets in the last decade of the $20^{\text {th }}$ century has moved the regulatory framework of capital to the forefront of national and supranational policy makers. The extensive case law by the ECJ, which the Commission lists on its Internal Market website ${ }^{7}$, forms only one aspect of a larger-scale approach understood to improve the

\footnotetext{
${ }^{4}$ See sections 2, 3 and 4 of the Gesetz über die Überführung der Anteilsrechte an der Volkswagenwerk Gesellschaft mit beschränkter Haftung in private Hand [Law concerning the transfer of shares in the VW limited liability company in private hands] of 21 July 1960, published in Bundesgesetzblatt [Federal Gazette - BGBl.] 1960 I, 585, and BGBl. 1960 III, 641-1-1).

${ }^{5}$ See, e.g., Johannes Adolff, Turn of the Tide? The 'Golden Share' Judgments of the European Court of Justice and the European Capital Markets, 3 German L.J. No. 8 (2002), available at: http://www.germanlawjournal.com/article.php?id=170, at para. 9 (dealing with the ECJ's judgments of 4 June 2002 concerning the 'golden shares' under Belgian [C-503/99], Portuguese [C-367/98] and French company law [C-483/99]); see subsequently the Court's ruling on golden share provisions under the English company law, C-98/01, handed down on 13 May 2003, and Comission vs. Italy, C-174/04 as well as Commission vs. The Netherlands, C-282/04 and C-283/04, 28 September 2006.

${ }^{6}$ See Fritz W. Scharpf, Balancing Positive and Negative Integration. The Regulatory Options for Europe. MPIfG Working Paper 97/8. Cologne: Max-Planck-Institute for the Study of Societies, available at: http://www.mpi-fg-koeln.mpg.de/pu/workpap/wp978/wp97-8.html,

${ }^{7}$ See, supra, note 1.
} 
competitiveness of the European economy. ${ }^{8}$ Other elements of this policy initiative include rules pertaining to 'company law and corporate governance, accounting and auditing. ${ }^{9}$ Here, in particular, the 'European Company Law scene', so masterfully depicted in 1973 by Clive Schmitthoff $^{10}$, has been in dramatic motion for the last couple of years. The long-standing attempts at adopting a European Company Regulation and Directive (Societas Europaea - SE) ${ }^{11}$ as well as a Take Over Directive finally came to an end. The struggle over the statute for the SE lasted for three decades, twice the time it should take for the passing of a EU directive governing corporate takeovers in Europe, ${ }^{12}$ an undertaking that itself had been brought underway in $1989 .{ }^{13}$ Both attempts occupied a European administration working with many of its Member States towards

8 See the Commission's website's announcement regarding the improvement of the 'regulatory framework', in which European companies operate with a view to making them competitive 'in global markets', available at: http://ec.europa.eu/internal_market/top_layer/index_45_en.htm (last visited on 27 October 2007).

${ }^{9}$ Id.

${ }^{10}$ Clive Schmitthoff, The Future of the European Company Law Scene, in: ibid., The Harmonisation of European Company Law, 3 (1973).

${ }^{11}$ E. Werlauff, The SE Company - A New Common European Company from 8 October 2004, 14 European Business Law Review [EBLR] 85-103 (2003); Christoph Teichmann, The European Company - A Challenge to Academics, Legislatures and Practitioners, in: 4 German L. J. 309 (2003), available at: http://www.germanlawjournal.com; Vanessa Edwards, The European Company - Essential Tool or Eviscerated Dream? 40 Common Market Law Review 443-464 (2003); S. Ebert, The European Company on the Level Playing Field of the Community, 14 European Business Law Review [EBLR] 183-192 (2003); T. L. Blackburn, The Societas Europea: The Evolving European Corporation Statute, 61 Fordh. L. Rev. 695-772 (1993).

${ }^{12}$ B. Pettet, Private versus Public Regulation in the field of Takeovers: The Future under the Directive, European Business Law Review [EBLR] 381-388 (2000); Klaus-Jürgen Hopt, European Takeover Regulation: Barriers to and Problems of Harmonizing Takeover Law in the European Community, in Klaus-Jürgen Hopt and Eddy Wymeersch (eds.), European Takeovers. Law and Practice (1992); Ronald J. Gilson, The Political Ecology of Takeovers: Thoughts on Harmonizing the European Corporate Governance Environment, id.

13 Theo Raaijmakers, Takeover Regulation in Europe and America: The Need for Functional Convergence, in Joseph A. McCahery/Piet Moerland/Theo Raaijmakers/Luc Renneborg (eds.), Corporate Governance Regimes. Convergence and Diversity (2002). 
a 'level playing field' of companies in Europe. ${ }^{14}$ While during the 1990s, one would have had the impression of European company law integration losing its long-term momentum ${ }^{15}$, this clearly changed in the context of the continuing debates over a European Company and a European Take Over Directive, both fuelled by increasingly denationalising investor activities and pressures to adopt domestic regulatory frameworks to global demands for improved corporate disclosure and investment opportunities. ${ }^{16}$ Finally, with the breakthrough at the 2000 Nice Summit for the SE statute, which subsequently got adopted in 2001 and went into force in October 2004, on the one hand, and with the all-exhausting passage of an eventually, much watered-down Takeover Directive ${ }^{17}$ by the European Parliament in December 2003, on the other, this long persisting stasis seemed to have come to an end. Moreover, the European Commission had seized upon the widespread uneasiness with the state of affairs to install an expert commission, whose first mandate had been to extrapolate the existing resistances against a European takeover régime and to develop a model that would be likely to satisfy the opponents. ${ }^{18}$ With the group of experts', under the direction of Dutch law professor, Jaap Winter, presenting the report shortly after, the Winter group received a follow-up mandate, which might be seen as the starting point of a new phase in European company lawmaking: the group launched a

${ }^{14}$ See already Commissioner Karel von Miert's speech at the 1998 Davos World Economic Forum, "What does a level playing field mean in the global economy?”, available at http://ec.europa.eu/comm/competition/speeches/text/sp1998_031_en.html (last visited 27 October 2007)

15 Jan Wouters, European Company Law: Quo Vadis? 37 Common Market Law Review 257-307 (2000).

${ }^{16}$ See, e.g., Matthias Casper, German capital market law - a permanent reform, 5 German L.J. 367 (2004), at 367, available at:

http://www.germanlawjournal.com/article.php?id=412.

${ }^{17}$ Silja Maul/Athanasios Kouloridas, The Takeover Bids Directive, 5 German L. J. 355-

366 (2004), at

http://www.germanlawjournal.com/pdf/.Vol05No04/PDF_Vol_05_No_04_355-

366_Private_Maul_Kouloridas.pdf.

${ }^{18} \mathrm{~J}$. Winter, 'Report of the High Level Group of Company Law Experts on Issues related to Takeover Bids', (2002) at http://europa.eu.int/comm/internal_market/company/docs/takeoverbids/2002-01-hlgreport_en.pdf. 
comprehensive online consultation on an outline for a 'Modernized Company Law in Europe'-three months after presenting the first report to the public. ${ }^{19}$ The second report by the High Level Group was made available after a careful analysis of the input from the online consultation in November 2002. ${ }^{20}$ Soon after, in May 2003, the European Commission issued its Communication to the Council and the European Parliament: 'Modernising Company Law and Enhancing Corporate Governance in the European Union - A Plan to Move Forward' ('Action Plan'). ${ }^{21}$

In the two years since the Commission's Action Plan, the Commission has brought on the way a number of initiatives that build on the detailed programme laid out in 2003. ${ }^{22}$ These initiatives are developed against the background of intense reform debates in the various Member States, not only with regard to the apparently inevitable move towards independent directors as mandated by the USA's 2002 Sarbanes-Oxley Act, ${ }^{23}$ but also in light of increasing pressure on existing systems of corporate management and industrial relations, in particular Germany’s model of co-

${ }^{19}$ See

http://europa.eu.int/comm/internal_market/en/company/company/modern/index.htm.

${ }^{20}$ See J. Winter, 'Report of the High Level Group of Company Law Experts on A Modern Regulatory Framework for Company Law in Europe', (2002) at

http://europa.eu.int/comm/internal_market/en/company/company/modern/consult/report_ en.pdf.

${ }^{21}$ Available at: http://europa.eu.int/eur-lex/en/com/cnc/2003/com2003_0284en01.pdf.

${ }^{22}$ For an updated overview, see

http://europa.eu.int/comm/internal_market/company/index_en.htm and

http://europa.eu.int/comm/internal_market/company/ecgforum/index_en.htm.

${ }^{23}$ J. N. Gordon, 'Governance Failures of the Enron Board and the New Information Order of Sarbanes-Oxley', (2003) Harvard John M. Olin Center for Law, Economics, and Business, Discussion Paper No. 416 (April), papers.ssrn.com/sol3/papers.cfm?abstract_id=391363 at http://www.law.columbia.edu/center_

program/law_economics/wp_listing_1/wp_author?exclusive=filemgr.download\&file_id= 69105\&rtcontentdisposition=filename\%3DWP216.pdf; R. Thompson, 'Corporate

Governance After Enron: The First Year', (2003) Vanderbilt University Law School, Law \& Economics, Working Paper No. 03-13,

papers.ssrn.com/sol3/papers.cfm?abstract_id=429622 at www.ssrn.com 
determination. ${ }^{24}$ Such activities, then, are being pursued in a complex regulatory environment of domestic statutory law on the one hand, and of norms produced by transnational regulatory bodies on the other. ${ }^{25}$ One result of this transnationalization of corporate law norm generation is that the negotiation of regulatory approaches to questions of corporate control, ownership and - not least - responsibility ${ }^{26}$ - is taking place today under conditions that differ markedly from traditional international law making. The emerging regulatory environment is at once discursively open to experiences and proposals coming forth from norm entrepreneurs that comprise both public, private and hybrid actors such as national governments and courts, but also corporations, expert commissions, and supranational standard setting organizations. ${ }^{27}$ But it is also more accentuated with regard to the degree to which legislative policies and domestic path dependencies of political choices and historical, socioeconomic developments, which shaped a particular regulatory regime, are coming to the fore. As a result, the choices available to law making bodies on the transnational level are not confined to different models of 'harmonization' on the one hand and 'regulatory competition' on the other. ${ }^{28}$ Instead, the proliferation of norm entrepreneur contributes to a

24 See, e.g., Theodor Baums, Interview: Reforming German Corporate Governance: Inside a Law Making Process of a very new nature, (2001) 2 German L. J. at: http://www.germanlawjournal.com/past_issues.php?id=43; Klaus-Jürgen Hopt, Corporate Governance in Germany, in Klaus-Jürgen Hopt and Eddy Wymeersch (eds.), Capital Markets and Company Law (2003); see also Jens Dammann, The Future of Codetermination after Centros: Will German Corporate Law move closer to the U.S. Model? 8 Fordham Journal of Corporate \& Financial Law 607 (2003).

25 See e.g. the overview of corporate governance codes in Europe, issued and constantly updated by the European Corporate Governance Institute (ECGI), at http://www.ecgi.org/.

${ }^{26}$ See Simon Deakin and Suzanne Konzelmann, Corporate Governance after Enron: An Age of Enlightenment, in: After Enron: Improving Corporate Law and Modernising Securities Regulation in Europe and the US, 155 (Joseph McCahery \& John Armour eds., 2006).

${ }^{27}$ For an in-depth discussion of this regulatory environment, see Gralf-Peter Calliess/Peer Zumbansen, Rough Consensus, Running Code: A Theory of Transnational Private Law, forthcoming.

${ }^{28}$ Peer Zumbansen, Spaces and Places: A Systems Theory Approach to Regulatory Competition in European Company Law, 12 Eur. L. J. 534 (2006); Peer Zumbansen, The 
more complex law-making environment, in which political choices are constantly challenged by other considerations and models of market ordering, including moral values and economic concepts. In addressing the regulatory challenge as to which norms are most appropriate to the governance of the corporation in a globally competitive setting, boundaries between company and capital markets law become as relative as those between corporate governance, corporate social and environmental responsibility, and industrial relations. To be sure, the transnational reality of norm creation challenges the role and competence of traditional law-makers as they enter a de-nationalizing market of norms and ideas. By way of illustration, that the European legislator should concern itself with issues as precarious and contested as executive compensation, ${ }^{29}$ while the Court of Justice marches on with increasing pressure on Member States' rules on company seats, ${ }^{30}$ are clear signs of an ever-faster diversifying agenda for Brussels' European company law programme, which can be properly understood only in relation to the transnational discursive and regulatory environment just described.

This background sheds a particular light on the recent series of 'golden shares' decisions handed down by the ECJ. The most recent, Volkswagen decision goes to the heart of the ongoing reform policies of European company law, while powerfully touching on the long-standing debate over converging corporate governance standards. While there is an important body of literature underlining the relevance of historical trajectories and associated competitive advantages to national differences (the so-called

Parallel Worlds of Corporate Governance and Labor Law, 13 Ind. J. Glob. Leg. Stud. 261 (2006).

${ }^{29}$ See the Commission Recommendation of 14 December 2004, available at: http://europa.eu.int/comm/internal_market/company/directors-remun/index_en.htm.

${ }^{30}$ Kilian Bälz/Theresa Baldwin, The End of the Real Seat Theory (Sitztheorie): the European Court of Justice Decision in Ueberseering of 5 November 2002 and its Impact on German and European Company Law, in: No.12 3 German L. J., available at: http://www.germanlawjournal.com/current_issue.php?id=214; C. Kersting/C. C. Schindler, The ECJ's Inspire Art Decision of 30 September 2003 and its Effects on Practice, (2003) 4 German L. J. 1277-1291; Walter Bayer, Die EuGH-Entscheidung Inspire Art und die deutsche GmbH im Wettbewerb der europäischen Rechtsordnungen, BetriebsBerater 2357-2366 (2003). 
Varieties of Capitalism school ${ }^{31}$ ), there is wide agreement that these distinct national systems are under severe and growing pressure to converge. ${ }^{32}$ The privatization of public welfare systems and the increased tendency to base pension and retirement financing on the capital market ${ }^{33}$ have coincided with a worldwide competition for stock market investments. ${ }^{34}$ As a consequence, traditional stakeholder-oriented systems of corporate governance are increasingly challenged as to their capacity to provide the transparency and management control necessary for their success in the global competition for investments. ${ }^{35}$

${ }^{31}$ Peter A. Hall/David Soskice, An Introduction to Varieties of Capitalism, in: Varieties of Capitalism. The Institutional Foundations of Comparative Advantage 1 (Hall/Soskice Ed. 2001); David Soskice, Divergent Production Regimes: Coordinated and Uncoordinated Market Economies in the 1980's and 1990's, in: Continuity and Change in Contemporary Capitalism 101 (Kitschelt/Lange/Marks/Stephens Ed. 1999); Ronald Dore/William Lazonick/Mary O'Sullivan, Varieties of Capitalism in the Twentieth Century, 15 Oxford Review of Economic Policy (Oxford Rev. Econ. Pol'y) 102 (1999); Robert Boyer, Coherence, Diversity, and the Evolution of Capitalisms - The Institutional Complementarity Hypothesis, 2 Evol. Inst. Econ. Rev. 43 (2005), 45-47; see also Matthew Allen, The varieties of capitalism paradigm: not enough variety?, 2 SocioEconomic Review 87 (2004).

${ }^{32}$ See, e.g. Eddy Wymeersch, Convergence or Divergence in Corporate Governance Patterns in Western Europe?, in: Corporate Governance Regimes. Convergence and Diversity 230 (Joseph McCahery/Piet Moerland/Theo Raaijmakers/Luc Rennebog eds., 2002); Peer Zumbansen, European Corporate Law and National Divergences: The Case of Takeover Law, 3 Wash U Glob Stud L. Rev. 867 (2004); Mathias Siems, Die Konvergenz der Rechtssysteme im Recht der Aktionäre (2006).

${ }^{33}$ Friedrich Kübler, The Impact of Equity Markets on Business Organization: Some Comparative Observations Regarding Differences in the Evolution of Corporate Structures, 2 European Business Organization Law Review [EBOR] 669 (2001); Friedrich Kübler, The Rules of Capital Under Pressure of the Securities Markets, in: Capital Markets and Company Law 95 (Hopt/Wymeersch Ed. 2003).

${ }^{34}$ Theodor Baums, Interview: Reforming German Corporate Governance: Inside a Law Making Process of a very new nature, 2 German Law Journal at: http://www.germanlawjournal.com/past_issues.php?id=43 (2001); Theodor Baums, Company Law Reform in Germany, 3 J. Corp. L. Stud. 181 (2003).

${ }^{35}$ Henry Hansmann/Reinier Kraakman, Toward a Single Model of Corporate Law?, in: Corporate Governance Regimes. Convergence and Diversity 56 (McCahery/Moerland/Raaijmakers/Renneborg eds. 2002). 
The Volkswagen decision brings these conditions into sharper focus yet. As was to be expected, the Court found it comparatively easy to identify the Volkswagen provisions to be in violation with the Treaty's free movement of capital guarantees.

A closer look at the Court's reasoning as well as at the context in which this case has been decided sheds light on the dynamics between creating a European competitive business environment on the one hand and doing justice to the political choices at the Member State level on the other. One week after the ECJ's decision, Lower Saxony's premier announced that his government planned a revision of the Volkswagen statute that would accommodate the Court's ruling while respecting the historical 'compromise' of $1959 .{ }^{36}$ This compromise had resulted in giving the capital owners, the Unions and the government a representative and codeciding stake in Volkswagen with the effect of 'protecting' the company from domination through one shareholder. ${ }^{37}$ Considering the prominence of the theme of co-determination within the global debate over the convergence or divergence of corporate governance standards ${ }^{38}$, the Volkswagen case offers a dramatic perspective on the regulatory multilevel dynamics of contemporary corporate law making. It opens - for a final encore? - the curtain for the Rhenish model of capitalism, behind which government, corporations and unions are understood as partners in a market ordering exercise. ${ }^{39}$ The political-social compromise, which has marked the German post-war economic order during the Bonn Republic has been under quite some strain with the deepening process of European

\footnotetext{
36 “VW Gesetz soll wiederbelebt werden”, Frankfurter Allgemeine Sonntagszeitung (online edition), 27 October 2007, available at:

http:/www.faz.net/s/RubD16E1F55D21144C4AE3F9DDF52B6E1D9/Doc E238C927C CDBC4EED9C79CEE5DD0506CD ATpl Ecommon Scontent.html (last visited 28 October 2007).

${ }^{37}$ See ECJ, Case C-112/2005, dated 23 October 2007, Commission v. Federal Republic of Germany "Volkswagen”, paragraph 22; see also, infra, sub B I.

${ }^{38}$ For references, see Jens Dammann, The Future of Codetermination after Centros: Will German Corporate Law move closer to the U.S. Model? 8 Fordham Journal of Corporate \& Financial Law 607 (2003)

${ }^{39}$ See only Michel Albert, Capitalisme contre Capitalisme (1991).
} 
integration and the exposure of national markets to global competition. ${ }^{40}$ As a result, past national political trajectories have not necessarily been found to provide a clear guide towards future developments - instead, as documented by the diversification and proceduralization of supra-national law-making in the areas of social policy, employment and now corporate ${ }_{\text {law }}{ }^{41}$ - they have become contested variables in a search of best practices. The Volkswagen decision must be seen as a crucial contribution to this search.

\section{THE HOLDING AND CONTEXT OF THE VOLKSWAGEN DECISION OF 23 OCTOBER 2007}

The Volkswagen Decision of 23 October 2007, instantly emphasized as a milestone in Europe's development of an open market ${ }^{42}$, was announced five and a half years after the ECJ had delivered the initial three judgements on the compliance of national golden share agreements with the free movement of capital under Art. 56 EC. ${ }^{43}$ Some of Europe's most visible symbols of economic protectionism had effectively been targeted

${ }^{40}$ Friedrich Kübler, The Impact of Equity Markets on Business Organization: Some Comparative Observations Regarding Differences in the Evolution of Corporate Structures, 2 European Business Organization Law Review [EBOR] 669 (2001)

${ }^{41}$ Catherine Barnard/Simon Deakin, In search of coherence: social policy, the single market and fundamental rights, 31 Industrial Relations Journal, 331-345 (2000); Catherine Barnard/Simon Deakin, 'Negative' and 'positive' harmonisation of labor law in the European Union, 8 Colum. J. Eur. L., 389 (2002); David Trubek/Louise Trubek, Hard and Soft Law in the Construction of Social Europe: The Open Method of Cooperation, 11 Eur. L. J. 343 (2005); Colin Scott, New-ish Governance in the EU and the Legitimacy of the EU, CLPE Research Paper 17/2007, available at: http://papers.ssrn.com/sol3/papers.cfm?abstract_id=1003824

42 See Landler, At Volkswagen, a historic change at hand, Herald Tribune (online edition), 22 October 2007; Ambrose Evans-Pritchard refers to the ECJ ruling as a "big breakthrough for the EU single market” in: Porsche poised to buy VW, The Telegraph (online edition), 24 October 2007.

${ }^{43}$ See, supra, note 5. 
by the Commission and by the Court. ${ }^{44}$ In order, however, to better assess the possible consequences of this newest development, an in-depth analysis of the reasoning of the Volkswagen Decision is necessary.

\section{A. THE COURT’s REASONING}

The European Commission filed an action under Art. 226 EC against the Federal Republic of Germany on 4 March 2005. ${ }^{45}$ The Volkswagen statute contained three provisions that the Court found to be in violation of the EC Treaty provision on the free movement of capital. First, section $2(1)^{46}$ of the Volkswagen Statute caps the voting rights each single shareholder can exercise to 20 percent of the company's overall voting rights, secondly, paragraph $4(3)^{47}$ provides that the quorum that is needed for an approval of a management resolution is - other than the statutorily needed quorum of 75 percent - increased to 80 percent. Finally, paragraph $4(1)^{48}$ grants the Federal State and the Land of Niedersachsen the right to appoint two

${ }^{44}$ Landler, Porsche to raise stake after court strikes down 'Volkswagen Law', Herald Tribune (online edition), 23 October 2007; the relevance of the ECJ's golden share judgments for the Volkswagen Law had already been pointed out by Hartmut Krause in the year 2002, see Hartmut Krause, Von "goldenen Aktien" dem VW-Gesetz und der Übernahmerichtlinie, Neue Juristische Wochenschrift 2747 (2002).

${ }^{45}$ See the Commission Application for Case C-112/05 of 4 March 2005, available at: http://www.curia.europa.eu/jurisp/cgi-bin/form.pl?lang=en.

${ }^{46}$ Paragraph 2 (1) of the Volkswagen statute provides: "The voting rights of a shareholder whose par value shares represent more than one fifth of the share capital shall be limited to the number of votes granted by the par value of shares equivalent to one fifth of the share capital."

${ }^{47}$ Paragraph 4 (3) of the Volkswagen statute provides: "Resolutions of the general meeting which, under the Law on public limited companies, require the favorable vote of at least three quarters of the share capital represented at the time of their adoption, shall require the favorable vote of more than four fifths of the share capital represented at the time of that adoption."

${ }^{48}$ Paragraph 4 (1) of the Volkswagen statute provides: "The Federal Republic of Germany and the Land of Lower Saxony (Niedersachsen) may each point two members of the supervisory board on condition that they hold shares in the company." 
members of Volkswagen's supervisory board on condition that they are shareholder in the company.

Before assessing each of these provisions in detail, the ECJ addressed the German submissions to the proceedings. In effect, the German government had argued that the Volkswagen statute ought not be regarded as a 'national measure', since it had arguably emerged from a contract between individuals and groups, which had - during the post-war years - claimed rights in respect of the then ownerless Volkswagen company. ${ }^{49}$ In transposing this very agreement into a statute, the German state had merely exercised its formal legislative power without passing a substantive legislative act. ${ }^{50}$

The ECJ took issue with this contention and found the adoption of the Volkswagen statute "a manifestation par excellence of state authority." 51 It held that since the contested provisions were based on an act of the German legislation and that the German legislator alone was entitled to modify or rescind the Volkswagen statute, the statute could not be regarded as a private law agreement but constituted a national measure.

At first glance, this scrutiny might seem to be of lesser importance when compared to the voting restrictions and their alleged infringement of Art. 56 EC. The historical events that gave rise to Germany's argument concerning the 'national measure', however, lend the dispute a highly symbolic dimension. In 1959, an agreement between the workers and trade unions of Volkswagen on the one hand and the Federal State and the state of Lower Saxony on the other concluded an ongoing dispute about the ownership of the then legally ownerless but flourishing Volkswagen undertaking. This dispute arose in the aftermath of WW II due to a set of unique circumstances, characterized not only by the remarkable dynamics of Volkswagen's post-War economic success but also by the firm's specific stakeholder constellation. After WW II, the Volkswagen factory, promptly recommenced operations in 1945. As it was located in the

49 See: Opinion of Advocate General Ruiz-Jarabo Colomer, delivered on 13 February 2007, Case C-112/05, Commission v. Federal Republic of Germany "Volkswagen”, paragraphs $25-26$.

${ }^{50}$ See, supra, note 49, paragraph 45.

${ }^{51}$ See, supra, note 37, paragraph 27. 
British occupied zone, the British military government temporarily assumed the decisive power to determine the fate of the factory. When the British withdrew from the occupied zone having failed in their attempts to sell the company to one of its competitors, Volkswagen became virtually ownerless. $^{52}$

Notwithstanding, the 'ownerless' Volkswagen factory, flourished as a business during the end of the 1940s and the 1950s. During the 1950s several claims with regard to the ownership of the company were asserted. Amongst those claiming ownership were those who had, on a weekly basis, contributed payments to facilitate the erection of the plant during the 1930s. Such efforts were expected to culminate in the opportunity to purchase one of the VW cars, the so-called Kraft durch Freude- Wagen ('strength through happiness' car). ${ }^{53}$ Therefore after the British had ceded responsibility for the company, the company's employees, the unions as well as the Federal state and the Land of Lower Saxony put forward their ownership claims. ${ }^{54}$ This dispute and a number of related court procedures concerning the ownership eventually contributed to a destabilization of the company. With VW having been a powerful symbol of German productivity and the country's innovative capacities, the five parties agreed on a compromise that took the form of a multilateral contract. Under this contract, the employees and trade unions agreed to abandon their alleged rights in VW if the State were to guarantee their protection against any single controlling shareholder. ${ }^{55}$ The provisions contained in this agreement later formed the Volkswagen statute. ${ }^{56}$

The Court had to address several aspects of the Volkswagen statute. Yet, given the particular context of converging corporate governance regimes in Europe against the background of a worldwide search for better

\footnotetext{
${ }^{52}$ See, supra, note 49, paragraph 24.

53 The former name Volkswagen (people's car) was dismissed by Hitler in 1939, see, supra, note 49, paragraph 20.

${ }^{54}$ See, supra, note 49, paragraph 25.

${ }^{55}$ See, supra, note 37, paragraph 22 and 23.

${ }^{56}$ For a historical overview of the Volkswagen law, see, supra, note 49, paragraph 17 to
} 29. 
corporate governance principles, the Court's reluctance of engaging at a deeper level with this particular set of circumstances during its assessment of the first contested provision of the statute, is remarkable. It would have been appropriate to emphasize the particular historical circumstances that gave rise to the contested contract.

\section{RESTRICTIONS OF THE FREE MOVEMENT OF CAPITAL}

The European Commission had filed the action against the German state claiming that the relevant provisions of the Volkswagen statute infringed both the free movement of capital (Art. 56 EC) and the freedom of establishment (Art. 43 EC). The ECJ scrutinized whether the provisions of the Volkswagen statute complied with the EC's fundamental freedom of free movement of capital. Therefore the ECJ first emphasized that the legal frame that had enabled the state to exercise a considerable influence on the company's governance, had been developed by the provision in Section 4 (3), which allowed the public sector - in fact the Land of Lower Saxony $^{57}$ - to preserve a comfortable blocking minority with regard to major decisions of the company's management. Secondly, this degree of influence would be supplemented by Section 2 (1), which capped the voting rights for every shareholder at 20 percent. $^{58}$ Since the two provisions taken together could at least potentially deter direct investors from other Member States the Court recognized a restriction of the freedom under Art. 56 paragraph 1 EC. ${ }^{59}$

With regard to Section 4 (1) of the Volkswagen statute, the Court found that the right of the Federal State and Lower Saxony to appoint two representatives to the supervisory board (Entsenderecht) infringed the free movement of capital. The Court found the provision to be granting the authorities a level of influence disproportionate to their actual investments.

\footnotetext{
${ }^{57}$ The German Federal State has sold its shares and is, therefore, no shareholder of the Volkswagen plc anymore.

${ }^{58}$ See, supra, note 37, paragraph 51.

${ }^{59}$ See, supra, note 37 , paragraph 56 .
} 
Section 4 (1) of the Volkswagen statute would therefore constrain the other shareholders' possibilities both to effectively participate in the management of the company. Consequently, it would also be liable to deter direct investors from other Member States from investing in the company's capital. $^{60}$

\section{JUSTIFICATION OF THE RESTRICTIONS}

Finally, the ECJ rejected Germany's submission according to which the contested provisions of the Volkswagen statute are at least justified by "overriding reasons in the general interest". Those would - due to its history - be included in the law itself and could be expressed as "equitable balance of powers". 61

In accordance with its settled case law ${ }^{62}$ the ECJ scrutinized whether a restriction of a fundamental freedom could be justified under the EC. Some, however narrow, justifications could arise within the context of certain domestic tax issues or of public security as stated in Art. 58 EC. ${ }^{63}$ Outside of these justifications not applicable in this case, a nondiscriminatory restriction could be justified by overriding reasons in the

\footnotetext{
${ }^{60}$ See, supra, note 37, paragraph 66.

${ }^{61}$ See, supra, note 37 , paragraph 70 ; the argument of the German state refers to the origin of the Volkswagen statute as an agreement between the then participating economic actors, see above, supra, note 49 .

62 E.g. ECJ, Case C-483/99 of 4 June 2002, Commission v. French Republic "Soiété Nationale Elf Aquitaine”, paragraph 45; ECJ, Case C-463/00 of 13 May 2003, Commission v. Kingdom of Spain, paragraph 68.

${ }^{63}$ Art. 58 (1) of the EC provides: "The provisions of Article 56 shall be without prejudice to the right of Member States: (a) to apply the relevant provisions of their tax law which distinguish between taxpayers who are not in the same situation with regard to their place of residence or with regard to the place where their capital is invested; (b) to take all requisite measures to prevent infringements of national law and regulations, in particular in the field of taxation and the prudential supervision of financial institutions, or to lay down procedures for the declaration of capital movements for purposes of administrative or statistical information, or to take measures which are justified on grounds of public policy or public security”.
} 
general interest. ${ }^{64}$ Accordingly, each Member State is generally entitled to define the standard of protection for the general interest. This entitlement is, however, limited again by the Treaty and, in particular by the principle of proportionality. In order to comply with the latter, the "measures adopted (must) be appropriate to secure the attainment" of the pursued objective and go not beyond what is necessary in order to attain it. ${ }^{65}$

The ECJ held that Germany had failed to provide sufficient justification for the voting restrictions. It rejected Germany's contention that the voting restrictions served the protection of interests of employees and of minority shareholders. While the Court recognized with regard to the latter, that the "desire to provide protection for such shareholders may also constitute a legitimate interest" ${ }^{\prime 6}$, it did not find the concrete voting restrictions to be conducive to that end. Remarkable is the Court's use of the word "also" in the given context, as this can only be read as an implicit reference to the employees’ interests, mentioned just before.

Another statement in the Court's opinion seems in odd contrast to its careful, if not reluctant engagement with the issue of protected interests in the remainder of the opinion. When the ECJ found that the German government had failed to explain how the contested provisions of the Volkswagen statute are appropriate and necessary to preserve the jobs generated by Volkswagen activity ${ }^{67}$, this can in fact be understood as another reference to the arguments raised in conjunction with the restrictions protecting a legitimate interest. While this line of interpretation may already border on speculation, the concrete wording of the here

${ }^{64}$ ECJ, Case C-483/99 of 4 June 2002, Commission v. French Republic "Soiété Nationale Elf Aquitaine”, paragraph 45; ECJ, Case C-463/00 of 13 May 2003, Commission v. Kingdom of Spain, paragraph 68.; According to ECJ, Case C-98/01 of 13 May 2003, Commission v. United Kingdom of Great Britain and Northern Ireland, paragraph 49 and ECJ, C-282/04 of 28 September 2006, Commission v. Kingdom of the Netherlands, paragraph 35, each Member State, whose provisions are subject to a procedure according to Art. 226 EC is obliged to submit factual circumstances that the respective restrictions are justified by overriding requirements of general interest.

${ }^{65}$ See, supra, note 37 , paragraph 73.

${ }^{66}$ See, supra, note 37, paragraph 77.

${ }^{67}$ See, supra, note 37 , paragraph 80. 
referred-to passages suggests that the Court was not entirely blind to the basis of the contentions made by the German government. Compared to the formal argument with which the Court found the VW statute to be a "national measure" 68 , its reasoning with regard to the voting restrictions does signal the Court's awareness of the particularity of the arguments brought by the German government.

\section{Preparation of the Decision by Advocate General RUIZ-JARABO COLOMER'S OPINION}

For observers, the Court's ruling could hardly have come as a total surprise. Looking at the carefully phrased Opinion by Advocate General (AG) Colomer of 13 February 2007, the general outline of the case had become visible already some time ago. Remarkably, the same AG had already authored the Opinions for previous actions against domestic golden share arrangements in other European Member States. ${ }^{69}$ As with many other cases, however, here too we find a certain discrepancy between the scope of issues addressed by the AG and those subsequently taken up by the Court.

\section{INFRINGEMENT OF ART. 56}

With regard to the alleged infringement of Art. 56 EC, the ECJ basically followed the Opinion delivered by AG Colomer. ${ }^{70}$ The AG had argued that the provisions of the Volkswagen Law constituted non-discriminatory restrictions, which objectively favoured the public authorities. "Those protectionist consequences", he reasoned, lead to a "dissuasive effect" of the Volkswagen statute to investors from other Member States, constituting - in accordance with the ECJ's settled case law - a violation

\footnotetext{
${ }^{68}$ See, supra, note 37, paragraph 26 to 29.

69 See the opinions delivered in the initial judgements on national golden share arrangements, see: ECJ, Case C-367/98, Commission v. Portugal; ECJ, Case C-483/99, See, supra, note 64; ECJ Case C-503/99, Commission v. Belgium.

${ }^{70}$ See, supra, note 49.
} 
of the free movement of capital. ${ }^{71}$ Since neither the protection of the employees' interests nor the protection of the minority shareholders was sufficient to constitute a general interest, the restrictions could not be justified. $^{72}$

\section{The AMBIVALENT ReLEVANCE OF ART. 295 EC IN the VolKSWAGEN DECISION}

As alluded to before, the Opinion of the AG contains remarkable considerations concerning Art. 295 EC. The Court, however, chose not to address these in its judgment at all. According to Art. 295 EC, "this Treaty [the EC] shall in no way prejudice the rules in Member State's governing the system of property ownership". In contrast to his earlier Opinions ${ }^{73}$, AG Colomer rejected the applicability of Art. 295 EC in the context of the Volkswagen statute. $^{74}$

He quite remarkably qualified it to be "curious" that the German government had not referred to Art. 295 EC. $^{75}$ This statement, presumably, derives from his formerly expressed views about the role of Art. 295 EC. In his Opinion, Art. 295 EC would entitle Member States, when privatizing formerly state-owned undertakings, to maintain extraordinary company rights by imposing golden share arrangements. ${ }^{76}$ The AG opined that if a Member State were free to decide whether an undertaking is either being thoroughly privatized or socialized, Art. 295 EC must a fortiori offer the possibility to partly privatize while enacting golden share arrangements (as a kind of "minus" to the complete privatization). ${ }^{77}$

${ }^{71}$ See, supra, note 49, paragraph 89.

72 See, supra, note 49, paragraph 103.

${ }^{73}$ See, supra, note 64.

${ }^{74}$ See, supra, note 49, paragraph 47 through 56.

${ }^{75}$ See, supra, note 49, paragraph 47.

76 See Stefan Grundmann/Florian Möslein, Die Goldene Aktie, Zeitschrift für Gesellschaftsrecht 319, (2003), 2003, at 339.

77 See Stefan Grundmann/Florian Möslein, Die Goldene Aktie, Zeitschrift für Gesellschaftsrecht 319, (2003), at 339. 
According to this argument, golden share arrangements would have to be subsumed under the term "rules in Member State's governing the system of property ownership" (Art. 295 EC) and, therefore, would fall outside of the purview of the EC Treaty.

Yet, the omitted references to Art. 295 EC are not curious at all if one considers that the ECJ had constantly rejected the applicability of Art. 295 EC in similar cases. In the Klaus Konle decision of 1997, the ECJ had briefly stated that Art. 295 EC did not have the effect of exempting a domestic system of property from the fundamental rules (which include the fundamental freedoms) of the Treaty. ${ }^{78}$ In other words, as long as a domestic statute infringed a fundamental freedom, the Member State should not be able to defend its golden share arrangements by mere reference to Art. $295 \mathrm{EC}^{79}$

The Volkswagen Opinion of the AG shows a drastic change of his former interpretation of Art. 295 EC. In his Opinion on the Volkswagen case, the AG dismissed the applicability of Art. $295 \mathrm{EC}$, as he found the present case to exhibit "substantial differences in relation to the cases, which the court has determined to date". ${ }^{80}$ The former judgements arose in the context of privatized undertakings. Central to those rulings had been measures, which "constituted means by which the public authorities could participate in certain activities of vital importance to the national economy, with the purpose of imposing an economic policy strategy" ${ }^{81}$ However, in the AG's view, the Volkswagen statute did not fall into this category, since it would concern neither one of the country's key branches nor a system of property ownership. ${ }^{82}$ Conclusively, the AG's formerly broad applicability of Art. 295 EC now seems reduced to domestic "key branches". But, since it remains entirely uncertain how those are to be

\footnotetext{
${ }^{78}$ ECJ, Case C-302/97, Klaus Konle v. Republic of Austria, paragraph 38.

${ }^{79}$ See also ECJ, Case C- 483/99, supra, note 62, paragraph 44.

${ }^{80}$ See, supra, note 49, paragraph 50 and 51.

${ }^{81}$ See, supra, note 49, paragraph 50.

82 See, supra, note 49, paragraph 51; Opinion in Cases C-367/98, C-483/99, C-503/99, supra, note 80, paragraph 62.
} 
identified in the first place ${ }^{83}$, the AG's interpretation of Art. 295 EC forfeits practicability.

\section{COMPATIBILITY OF THE VOLKSWAGEN DECISION WITH PREVIOUS ‘GOLDEN SHARE' JUDGMENTS}

As seen, the ECJ stuck with its previous judgements on golden share agreements. The definition of the term 'free movement of capital' is still informed by the nomenclature set out in Annex I to Council Directive 88/361/EEC of 24 June 1998. It, however, remains questionable whether a Directive can provide definition for terms of the Treaty itself. In order not to render the free movement of capital illusory ${ }^{84}$, no domestic instrument may be created if that instrument may be liable to actually or potentially impede foreign direct investors from acquiring a stake in the capital in order to participate in its management or in its control. In this reading, Art. 56 EC was a "general prohibition on restrictions on the movement of capital", which "goes beyond the mere elimination of unequal treatment on grounds of nationality". ${ }^{85}$ The Volkswagen decision, thus, builds nicely onto the string of cases, in which the Court has been executing a gradual shift from striking down discriminatory arrangements to the erection of parameters obliging member states to provide - within a specific proportionality test - justifications for arrangements seen as likely impediments for transnational commerce. ${ }^{86}$ With the Volkswagen decision, as with the golden share decisions before it, but also the other

\footnotetext{
${ }^{83}$ This is subject to ongoing political discussions throughout Europe, for instance, see Dietmar Hawranek/Christian Reiermann, Gutes Geld, böses Geld, Der Spiegel 27/2007, p. 84, 85; see also Daniel Saam, Protection for domestic core enterprises against direct investments by foreign-owned investment funds, 1 Legal Latitudes: Newsletter for the Transatlantic Business and Law Community 57 (2007), available at: http://www.osgoode.yorku.ca/legallatitudes/documents/Legal_Latitudes_Vol_01_ No_04.pdf (last visited 28 October 2007).

${ }^{84}$ ECJ, Case C-112/05, supra, note 2, paragraph 54 and 55; ECJ, Case C-483/99, supra, note 62, paragraph 41; ECJ, Case C-367/98, supra, note 69, paragraph 45.

${ }^{85}$ E.g. ECJ Case C-367/98, supra, note 69, paragraph 45.

${ }^{86}$ Adolff, supra, note 5, sub paragraph 2.
} 
highly prominent company law cases in $\operatorname{Centros}^{87}$, Ueberseering ${ }^{88}$ and Inspire $\mathrm{Art}^{89}$, the Court has continues to effectively strike into the lingering negotiations, contestations, deadlocks and entrenchments in Europe with regard to corporate mobility, the freedom of establishment and the free movement of capital. The institutional, law-making role of the Court within this multi-level regulatory scenario is as fascinating as is the set of substantive issues at stake. Thus, the Volkswagen decision constitutes another formidably challenging contribution to the already complex development of European corporate law. It is this combination of the interplay between the Commission's attempts at moving European company law forward with the different strategies of the member states to resist or to adopt to the 'pressure to reform' in light of globalizing capital markets on the one hand with the unique place held by the ECJ in this lawmaking laboratory on the other that makes the field a prime subject for the study of transnational law-making.

${ }^{87}$ Case C-212/97, Centros Ltd. v. Erhvervs-Org., 1999 O.J. (C 136) 3; see E. Wymeersch, Centros: A Landmark Decision in European Company Law, in T. Baums,K. J. Hopt and N. Horn (eds.), Corporations, Capital Markets and Business in the Law. Liber Amicorum Richard M. Buxbaum (2000); W. F. Ebke, Centros - Some Realities and Some Mysteries, 48 Am.J. Comp. L. 623 (2000); see also Harald Halbhuber, National Doctrinal Structures and European Company Law, 38 Common Market Law Review 1385-1420 (2001)

${ }^{88}$ Case C-208/00, Ueberseering BV v. NCC Nordic Construction Company Baumanagement GmbH, ECR 2000, I-9919; see hereto Kilian Bälz \& Teresa Baldwin, The End of the Real Seat Theory (Sitztheorie): The European Court of Justice Decision in Ueberseering of 5 November 2002 and its Impact on German and European Company Law, in 3 German L.J. No.12 (2002), available at http://www.germanlawjournal.com/current_issue.php?id=214; W.-H. Roth, 'From Centros to Ueberseering: Free Movement of Companies, Private International Law, and Community Law', 52 ICLQ 177-208 (2003)

${ }^{89}$ Case C-167/01, Kamer van Koophandel en Fabriken voor Amsterdam v. Inspire Art Ltd., 2003 O.J. (C 275) 10; see Kersting \& Schindler, The ECJ's Inspire Art Decision of 30 September and Its Effects on Practice, in 4 German L.J., 1277-91 (2003), available at http://www.germanlawjournal.com /article.php?id=344; 


\section{THE VOLKSWAGEN DECISION IN CONTEXT}

It would be no exaggeration to state that an assessment of what characterized European company law, would differ wildly if not from year to year than surely when comparing a several-year stretch of time with another. The regulatory agenda of the Commission, not least evidenced by the sheer omnipresence of Internal Market Commissioner, Charlie McCreevy $^{90}$, has been in a constant state of growth, refinement and differentiation. Any assessment, then, will be one of a process rather than of a reached endpoint. It is important to keep the mixed nature of European company law making in mind, when beginning to speculate about the impact of this recent, prominent judgment. Thus, trying to bear in mind the diversity of historically grown, socio-economic structures that gave rise to different company law regimes in the various member states, when evaluating a new company law judgment from the Court, is a necessary precondition to make sense of it, but is it sufficient? The level of activity of the Court must be seen in comparison and correlation with that which we can observe in Brussels. With an eye to the Court on the one hand, and another one on fast-evolving processes of 'company law reform' in member states all throughout the EU, the Commission has been a fast learner and adaptive facilitator of regulatory learning. The Commission has proven to be an initiator and apt consumer of company law related expertise needed to better understand the challenges to reform of a market finding itself enlarging at a dramatic pace, with the combined challenge to inspect existing and evolving regimes with a view to the West and to the East.

The Volkswagen Decision, then, was not a decision coming out of nowhere, nor would anybody suspect it to have little practical impact. Yet, the evaluation of the decision's impact poses a considerable number of challenges, given the complexity of the field described above. In the interest of narrowing our first attempts at an analysis, it is certainly fair to say that the decision was handed down in a context of legal and socioeconomic contestation of the way that corporate boards are to be staffed, controlled and that corporate power is being exercised. The mere mentioning of the company's name brought to the forefront of any debate

\footnotetext{
${ }^{90}$ http://ec.europa.eu/commission_barroso/mccreevy/index_en.htm
} 
about Volkswagen's future in the European and global market its famous, if much contested model of worker involvement, itself connected with the company's intriguing historical origins. It was in fact through the eyes of the many journalists, predominantly in Europe and in North-America, who instantly commented on the Court's ruling, that we have been beginning to discern the dimensions of the current form of Andrew Shonfield's "Modern Capitalism"91 and its possibly forming future trajectories. The state of nervousness that characterizes many observations of the present development is a mere reflection on the complexity we are facing when discussing forces of change, of convergence and divergence.

Once we begin, however, to look beyond the prominent place occupied by the questions concerning Volkswagen's co-determination in order to resituate these concerns within a larger framework of considerations about corporate governance and the mixed, public and private nature of the norms constituting that regime, comprised of hard and soft law, of direct and increasingly powerful, indirect forms of regulation, we are able to appreciate the unavoidably political nature of the current discussions about corporate governance. Looking at but also beyond co-determination forces us to take a closer look at the supporting regulatory and socio-economic frameworks in which co-determination but also corporate governance elements such as board structure, compensation, power allocation and shareholder structures are presently being reconfigured. Looking beyond co-determination as such, then, allows us to understand it as one element in a larger field of interrelated institutions that find themselves in dramatic change. It is for that reason, that, yes, the Volkswagen decision underlines the already long-held suspicion that corporate law is deeply political, but that there is, at the same time, more than that. It is important, but not sufficient to reread Berle’s “Twentieth Century Capitalist Revolution”92 to

\footnotetext{
${ }^{91}$ Andrew Shonfield, Modern Capitalism. The Changing Balance of Public and Private Power (1965)

92 Adolph A. Berle, The Twentieth-Century Capitalist Revolution (1954); see also Berle’s assessment of Shonfield, 82 Pol. Sc. Q. 628 (1967), where Berle attests Shonfield to have written "the first serious and scholarly review of the modern capitalist revolution", which he [Berle] places in a fruitful and complementing dialogue with Galbraith's The New Industrial State, finding that both authors concur in their assessment of the need to expand public control over private enterprise, recognizing that economic goals are diminishing in relative importance, gradually giving way to expertise-based, scientific
} 
understand the present forces at work in a transnational arena of public and private actors contesting and constantly redrawing the 'boundaries of the firm'. It is important to read Karl Polanyi ${ }^{93}$ today, but it is important to read it in the present context, which is marked by significant advances in the theory of institutional economics ${ }^{94}$, by a fast evolving expertise in the 'varieties of capitalism', 95 and theories of 'embeddedness',96 and comparative corporate law. ${ }^{97}$ It is against this background that contemporary assessments of corporate law have to be complemented by an analysis of the regulatory environment of companies on the one hand and their internal differentiation and ongoing experimentation as risktaking, profit-seeking, researching and developing organizations on the other. $^{98}$ It is only through the combination of these two perspectives that

considerations of societal development. Thanks to Osgoode Hall Ph.D. candidate, Fenner Kennedy-Stewart, for having pointed us to this review.

${ }^{93}$ Karl Polanyi, The Great Transformation (1944)

${ }^{94}$ Douglass C. North, Institutions, Institutional Change and Economic Performance (1991); Paul A. David, Why are institutions the 'carriers of history'?: Path dependence and the evolution of conventions, organizations and institutions, 5 Structural Change and Economic Dynamics 205-220 (1994); Daniel Kiwit \& Stefan Voigt, Überlegungen zum institutionellen Wandel unter Berücksichtigung des Verhältnisses interner und externer Institutionen, 46 ORDO 117-148 (1995)

${ }^{95}$ See, e.g. John W. Cioffi, Corporate Governance Reform, Regulatory Politics and the foundations of Finance Capitalism in the United States and Germany, 7 German L. J. 533 (2006), available at: http://www.germanlawjournal.com/article.php?id=732.

${ }^{96}$ See only Mark Granovetter, Economic Action and Social Structure: The Problem of Embeddedness, 91 American Journal of Sociology 481 (1985), and Mark Granovetter, The Impact of Social Structure on Economic Outcomes, 19 J. Econ. Persp. 33 (2005); see the ciritique by Jens Beckert, The Great Transformation of Embeddedness. Karl Polanyi and the New Economic Sociology, Max-Planck-Institut für Gesellschaftsforschung/MaxPlanck-Institute for the Study of Societies, MPIfG Discussion Paper 07/1 (2007), available at: http://www.mpi-fg-koeln.mpg.de/pu/mpifg_dp/dp07-1.pdf

${ }^{97}$ Klaus J. Hopt, Comparative Company Law, in: Oxford Handbook of Comparative Law 1161-1191 (Mathias Reimann/Reinhard Zimmermann eds., 2006), available at: http://www.ecgi.org/wp/wp_id.php?id=231; see earlier Mark J. Roe, Comparative Corporate Governance, in: The New Palgrave Dictionary of Law \& Economics (Peter Newman ed., 1998)

${ }^{98}$ Oliver E. Williamson, The Modern Corporation: Origins, Evolution, Attributes, $19 \mathrm{~J}$. Econ. Lit. 1537 (1981); William Lazonick, Innovative Enterprise and Historical Transformation, 3 Enterprise \& Society 3 (2002) 
we take the lessons of earlier, astute observers of the company seriously today.

Thus, drawing out the explicit and implicit aspects of the Volkswagen decision of 23 October 2007, can we understand it as part of a laboratory of contemporary corporate law making in progress. As journalists worldwide were fast to identify the central aspects and consequences of the ECJ's ruling ${ }^{99}$, we began to be alerted to what many believe was at stake in this case. In light of the long-standing emphasis on Germany's Rhenish capitalist company and industrial relations regime, the case was seen to strike at the heart of German corporate governance ${ }^{100}$, as it targeted one of Europe's foremost model companies of worker codetermination. When, however, a leading German newspaper pointed to that very fact while at the same time highlighting that this model did show - "often in disgusting manner"- the excesses of this regime ${ }^{101}$, the degree of contestation marking this field, onto which the Court found itself treading (or, rushing?), eventually began to emerge. Two aspects, in particular, make this case remarkable. For one, its concrete circumstances belie the general intention of this and the previous rulings intended not only against capital market barriers, but also in favor of opening up domestic markets for foreign investment. In the case of Volkswagen, the expected outcome of the ECJ's intervention into the Wolfsburg Comfort Zone is a cleared path for family-held Porsche to succeed in its longstanding attempt at acquiring a majority of Volkswagen. ${ }^{102}$ This is particularly poignant as the

99 See, e.g., EU court strikes down 'VW law', The Associated Press, 23 October 2007, MSNBC.com (online edition): "The decision is expected to have ramifications across Europe, where many governments have tried to protect companies they see as vital to their economies from takeovers, particularly foreign ones”; David Gow, Loss of Germany's VW law spells end of the road for golden shares, The Guardian, 24 October 2007 (online edition): “The judgment [...] sends a warning to protectionist governments keen to shield so-called strategic companies from 'foreign', often European, takeovers”.

100 Sean O'Grady, Porsche accelerates takeover plan as 'VW Law' rejected, The Independent, 25 October 2007 (online edition): “A piece of German industrial tradition was consigned to the scrapheap yesterday by the European Court of Justice”.

${ }^{101}$ Georg Meck, Der Porsche-Clan rüstet für die Zeit nach dem VW-Gesetz, Frankfurter Allgemeine Zeitung, 22 October 2007 (online edition).

102 Parmy Olson, Porsche Drives Over Volkswagen Law, Forbes.com, 23 October 2007: “Clever preparation by Porsche means that Tuesday's ruling by European Court of 
Volkswagen ruling comes, as we saw, in a ever accelerating series of Commission initiated legal actions against member states found to be entertaining protectionist policies. ${ }^{103}$ In the complex regulatory environment of European market integration, such policies have naturally been confronted with a host of member state reactions, often appealing to the national interest at stake. It is in this context, that both the French and German governments have recently undertaken attempts at identifying and protecting so-called 'core industries' ${ }^{104}$ It is a dynamic and tension-laden field, on which the Commission will continue on its quest to identify European based corporations with so-called special rights, an undertaking that has gained even more momentum with the recent Volkswagen ruling.

Meanwhile, the Volkswagen ruling is bound to have notable impacts on the German domestic labor regime. With Volkswagen becoming a likely takeover victim for Porsche after the ECJ's decision, something that DER SPIEGEL called the 'triumph of the Piechokratie'105, the fate of workers' co-determination in one of Germany's largest employers is in a precarious state. Central to the predicament is the competition between two models, which instead of complementing each other, have increasingly been positioned in an oppositional and, in fact, competitive relation. Workers' co-determination, as forming a constitutive part of the two-tier board

Justice against the so-called Volkswagen Law, which shields the carmaker from foreign takeovers, won't be ushering in a wave of suitors from overseas, but will pave the way for the luxury car manufacturer to take full control of its midmarket compatriot.”

103 See references, supra, note 5 .

104 See Daniel Saam, Protection for domestic core enterprises against direct investments by foreign-owned investment funds, 1 Legal Latitudes: Newsletter for the Transatlantic Business and Law Community 57 (2007), available at: http://www.osgoode.yorku.ca/legallatitudes/documents/Legal_Latitudes_Vol_01_No_04. pdf (last visited 28 October 2007), finding such initiatives not only in Europe, but also in the United States, with its northern neighbor Canada apparently taking a more inviting attitude towards FDI; See also David Gow, Loss of Germany's VW law spells end of the road for golden shares, The Guardian, 24 October 2007 (online edition), referring to French President Sarkozy's recent renationalization interventions in the gas and environment group, Suez.

105 Andreas Nölting, Der Triumph der Piechokratie, Spiegel Online, 23 October 2007, available at: http://www.spiegel.de/wirtschaft/0,1518,513012,00.html (last visited 28 October 2007). 
structure in German stock corporations with more than 500 employees, has been a constant target of critique and polemics, while its accompanying regime of Betriebsräte (work councils) continued to fare comparatively more favorably. ${ }^{106}$ Rushing in, biased observers fall victim to the long pronounced, comparative efficiency of works councils cooperating with corporate management in salvaging periods of crisis and austerity. Meanwhile, however, they might perhaps too easily dismiss board codetermination. ${ }^{107}$ Certainly, both sides are half correct, half mistaken. The signal sent to foreign investors by the German system of board codetermination has for some time now been received as at best a mixed one. ${ }^{108}$ Yet, to place all of one's hopes on works councils as an alternative to or possible substitute for co-determination in the hope of maintaining a working relationship between management and labor, risks prematurely cutting ties with a historically grown industrial relations regime, which not only comprised the role of unions in labor-capital negotiations, but also induced far-reaching policies regarding vocational training, workplace protection and, to a very limited degree, corporate decision making. ${ }^{109}$

${ }^{106}$ For a concise presentation and insightful assessment, see Manfred Weiss, Labor Law, in: Introduction to German Law 299 (Zekoll/Reimann Ed. 2006)

107 Melanie Amann, Sieg der Mitbestimmung, Frankfurter Allgemeine Zeitung, 24 October 2007 (online edition, 28 October 2007): "Und die Betriebsparteien wissen besser als der Gesetzgeber, wie ihre Machtverhältnisse geregelt sein sollen.“ See, in contrast, Peer Zumbansen, Ethikrichtlinien nutzen vor allem dem Arbeitgeber, Frankfurter Allgemeine Zeitung, 27 March 2007, available at: http://berufundchance.fazjob.net/s/Rub8EC3C0841F934F3ABA0703761B67E9FA/Doc EA1E68B94951848F5B77441750F152D40 ATpl Ecommon Scontent.html (last visited 28 October 2007).

108 See, e.g., Gary Gorton/Frank A. Schmid, Capital, Labor and the Firm: A Study of German Co-determination, 2 J. Eur. Econ. Ass. 863 (2004); for an excellent, balanced overview of the discussion, see Katharina Pistor, Co-determination in Germany: A SocioPolitical Model with Governance Externalities, in: Employees and Corporate Governance 163 (Margaret M. Blair \& Mark J. Roe eds., 1999); Mark J. Roe, for a set of historical analyses of the German codetermination regimes, see already Herbert J. Spiro, The Politics of German Codetermination (1958); Abraham Shuchman, Codetermination: Germany’s Middle Way in Germany (1957).

109 This has been a central contention among the "Varieties of Capitalism" scholars: see, e.g. Peter Hall \& David Soskice, Introduction to Varieties of Capitalism, in: Hall \& Soskice (eds.), Varieties of Capitalism: The institutional foundations of Comparative Advantage, 1 (2001); Kathleen Thelen, Varieties of Labor Politics in Developed Democracies, in: Hall \& Soskice, Varieties of Capitalism (2001), at 71; Kathleen Thelen, 
How effectively work councils will be able to negotiate the increasing tensions between the corporation and its employee stakeholders, will unfold within a highly contentious environment of business policy making. The room to manoeuvre for all implicated actors is likely to become smaller rather than bigger. The greatest victim of this fight over co-determination is, to be sure, a better understanding of the company, in particular of its internal and external environment, where employees, consumers, creditors and the 'society at large' are not merely stakeholders. Looking beyond the deeply entrenched classifications and demarcation lines along which shareholder interests are clearly distinguished from those of stakeholders, would allow us to return with a more sober look at the company itself. It would be here that we would begin to assess the role of employees as something more than an 'investor risk factor', but an essential, powerful asset for the firm's economic performance. Of course, it is unlikely that we would even be able to see that deep into the conundrical internal life of the corporation, while applying our shareholder/stakeholder, public/private distinctions to make sense of it all. Can it be really all that difficult to heed the insightful warnings of the past not to take such categorizations as depictions of reality, but rather to understand them as the semantic representation of difficult but deliberate choices? ${ }^{110}$ The dialogue between corporate lawyers and those studying the corporation and what that term implies ${ }^{111}$ has only just begun.

Beyond Continuity:Institutional Change in Advanced Political Economies (2005); Peer Zumbansen, Varieties of Capitalism and the Learning Firm: Contemporary Developments in EU and German Company Law, CLPE Research Paper 21/2007, available at: http://papers.ssrn.com/sol3/papers.cfm?abstract_id=993910, forthcoming in European Business Organization Law Review (2008)

110 Morris Cohen, Property and Sovereignty, 13 Cornell L. Q. 8 (1927); Robert Hale, Coercion and Distribution in a Supposedly Non-Coercive State, 38 Pol. Sc. Q., 470-478 (1923); Morris Cohen, The Basis of Contract, 46 Harv. L. Rev. 553 (1933); Duncan Kennedy, Form and Substance in Private Law Adjudication, Harv. L. Rev. 1685 (1976)

111 John Dewey, The Historic Background of Corporate Legal Personality, 35 Yale L.J. 655 (1926); Morton Horwitz, Santa Clara Revisited: The Development of Corporate Theory, 88 W. Virg. L. Rev. 173 (1986) 


\section{CONCLUSION}

In the here and now, while we are waiting for signs of the ECJ's decision's impact, they might be coming faster than expected. One day after the Court had rendered its judgment, the Arbeitsgericht (first instance labor court) Stuttgart in Germany, too, delivered a telling judgement. ${ }^{112}$ The court dismissed the request of Volkswagen's Betriebsrat (works council) for temporary relief (einstweiliger Rechtsschutz) against the pending registration of the newly established company structure of Porsche as a Societas Europaea. With their action, the workers at Volkswagen had hoped to prohibit either the registration and/or the co-determination covenant (Mitbestimmungsvereinbarung) between Porsche's employer and its employees, in fear of their own co-determination rights being dramatically compromised as a consequence of the new co-determination regime under the Porsche's Societas Europaea. This regime ${ }^{113}$ offers the employer and the employees the possibility to regulate the codetermination by mutual agreement before a fall-back clause kicks in, if the negotiations fail. ${ }^{114}$ The primary intention of the German SEBeteiligungsgesetz is to supply a legal framework for "customized forms of co-determination". ${ }^{115}$ Porsche and its own works council had made use

\footnotetext{
${ }^{112}$ Arbeitsgericht Stuttgart, Kammer Ludwigsburg, 12 BVGa 4/07 of 24 October 2007, available at: http://www.arbg-stuttgart.de/servlet/PB/show/1213597/12-BVGa-4-07.pdf.

${ }^{113}$ The regime has been established by the following legislative acts: Council Regulation (EC) No. 2157/2001 of 8 October 2001 on the Statute for a European company (SE); Council Directive 2001/86/EC of 8 October 2001 supplementing the Statute for a European company with regard to the involvement of employees; both available at: http://eur-lex.europa.eu/en/index.htm; The Regulation (EC) No. 2157/2001 is accompanied by a German implementation law called: Gesetz zur Ausführung der Verordnung (EG) Nr. 2157/2001 des Rates vom 8. Oktober 2001 über das Statut der Europäischen Gesellschaft (SE) (SE-Ausführungsgesetz - SEAG) of 22 December 2004, BGBl. I, 3675; whereas the Directive 2001/86 EC has been transformed into German law by Gesetz über die Beteiligung der Arbeitnehmer in einer Europäischen Gesellschaft (SEBeteiligungsgesetz - SEBG) of 22 December 2004, BGBl. I, 3675.

114 See Rüdiger Krause, Die Mitbestimmung der Arbeitnehmer in der Europäischen Gesellschaft,Betriebs-Berater 1221 (2005), at 1222, who describes the negotiations before the conclusion of the covenenat as "bargaining in the shadows of law".

${ }^{115}$ See, supra, note 114, at 1226; also, supra, note 112, II. 2. e) bb).
} 
of this possibility expressly stated in Section 21 SE-Beteiligungsgesetz ${ }^{116}$ by entering into a covenant on the Porsche employees' co-determination, to be arranged in the newly established SE.

One element, in particular, incited Volkswagen's main objection, namely a comparatively, because numerically equal allocation of Porsche and Volkswagen members to the supervisory board in the case that Porsche Automobil Holding SE acquired a major stake of Volkswagen shares. The Volkswagen employees argued that this allocation violated democratic principles. In the likely, even if not imminent case of Porsche acquiring a majority of Volkswagen shares at a time where the Porsche-VW codetermination battle is not put to rest and VW share prices soar ${ }^{117}$, the covenant would result in Volkswagen and Porsche being able to each delegate the same quorum of employee representatives to the supervisory board of the SE. In effect, Porsche's 12,000 employees would have the same influence within the supervisory board as Volkswagen's 324,000 employees. ${ }^{118}$ In light of such numbers, Volkswagen's objection that this allocation of representatives violated the Principle of Democracy becomes quite graphic. ${ }^{119}$ Following Porsche's lawyers, the Arbeitsgericht dismissed the action for temporary relief, with which the VW employees had tried to stop Porsche's triumph march. The Court essentially relied on the consideration that a dispute over the formal or substantive validity of an SE's co-determination covenant must not delay the registration of the

${ }^{116}$ Section 21 SE-Beteiligungsgesetz states that this covenant between the employer and a delegation of employees may determine how the supervisory board and the workers council are equipped.

117 Spiegel Online, 3 November 2007: Machtkampf: Porsche verschiebt VW-Aktienkauf [Power struggle: Porsche delays share acquisition of Volkswagen], available at: http://www.spiegel.de/wirtschaft/0,1518,515200,00.html (last visited 7 November 2007)

${ }^{118}$ Porsche worker would then have 30-times more influence as the vote of a Volkswagen worker, see Kai Lange, Angriff aufs Gewerkschaftsparadies in: Spiegel-Online, 24 October 2007, available at: http://www.spiegel.de/wirtschaft/0,1518,513024,00.html; Ansgar Siemens, Wenn sie zanken Seit' and Seit',Süddeutsche.de, 24 October 2007, available at: http://www.sueddeutsche.de/wirtschaft/artikel/786/139495/.

${ }^{119}$ Arbeitsgericht Stuttgart, decision of 24 October 2007, supra, note 112, at 10; see also the statement by IG-Metall (Germany’s largest singular trade union) Jürgen Peters, Angerichtetes Desaster, an interview by Janko Tietz in: Der Spiegel,29 October 2007, at 108. 
company. The Court explicitly recognized that the applicable norms of the German SE-Beteiligungsgesetz do not contain such an instrument, which as the Court observed - would constitute a considerable pressure instrument ("erhebliches Druckmittel"), ${ }^{120}$ one, however, that does not form part of the co-determination negotiation regime under the SE. Meanwhile, the Court underlined that the validity of the co-determination covenant would have to be assessed in a regular action as compared to the temporary relief action brought by the Volkswagen employees.

This case might be more than just a further ripple on the already troubled seas of European Company Law. The same seems true for the ECJ's Volkswagen case. The waters of European company law are travelled by tankers (The Commission), submarines (investment funds), yachts (Porsche), exploration boats (expert commissions) and large sailboats in a state of repair (the member states). Then there are the rafts, paddling boats and canoes, steered by practitioners and scholars. All these need to get to shore and climb the stairs to the Lighthouse from where to look out at what has become of Clive Schmitthoff's 'European Company Law Scene'. ${ }^{121}$ But, they also need to provide a directing light to the different sea-farers adventuring between London and Frankfurt, Paris and Amsterdam and Warsaw. And instead of merely noting that all are being carried this way or that by the winds of globalization, it might be timely to consider again, what different concepts of the corporation, des Unternehmens, la società, l'entreprise, are at stake in this windy weather.

\footnotetext{
${ }^{120}$ Arbeitsgericht Stuttgart, Kammer Ludwigsburg, 12 BVGa 4/07 of 24 October 2007, available at: http://www.arbg-stuttgart.de/servlet/PB/show/1213597/12-BVGa-4-07.pdf, at 10

${ }^{121}$ Supra, note 10.
} 